\title{
Deconstructing The Notion Of Human Genetic Causation: a Reflection Necessary To Face The Eugenic Threats That Emerge From The Rise Of Genetic Technologies
}

\author{
Dawidowski, Adriana Ruth \\ Instituto de Desarrollo Económico Y Social (IDES). Universidad Nacional de General Sarmiento. \\ Buenos Aires. Argentina — adriana.dawidowski@gmail.com
}

Introduction: Diagnostic techniques are living an euphoric cycle because of the genetic technologies applied to predictive diagnosis. Meanwhile anthropological and philosophical analysis understand these techniques as modern expressions of eugenic modelization of bodies and biologization of social relationships, and the medical institutions and physicians as intermediaries of this biopolitic. This could be rooted in the notion of gene that is assumed by this professional collective. Objective: to identify ideas and notions that can lead to construction of social relationships underpinned on the genetic of people. Methods: discourse analysis of medical interviews. 5 argentinean physicians from leading health institutions ( 3 oncologists (On), 1 endocrinologist (Endcr), and 1 genetic counsellor (GC) were interviewed during 2012 about their opinions and prescription practices on cancer genetic test. Results: The On and Endcr opinions are dominated by the preventive logic that is seen as a rule of higher order. They emphasize the biological heritage, the familial bonds and also the determination of sibling's life, health and quality of life. On the contrary the GC discourse, because of the arouse of the disease can be expressed in probabilistic terms, are oriented to enforce patient's autonomy regarding preventive measures. In spite the On and Endcr mention probabilities, their discourses are oriented to guarantee the patient's adherence to these measures. As a result genes are being expressed as sufficient causes of the disease. Conclusion and discusion: The analysis suggests that the medical concept of gene rests on the idea of causality, concealing the notion of probability and multicausality of cancer. This fact can be interpreted in the light of the notions of Mario Bunge of Determination and Causal Determination, in combination with the Theory of Complementarity from Ingold. This theoretical crossing enable to hypothesize that, as genetics is a pre-intervention instance respecto to the culture and the environment, medical discourse interprets it as a Causal Determination (in the sense of efficient cause): the temporal precedence reinforces the Western tradition to dissociate form and substance, enabling the analogy of the genotype as a design specification that can be completed with the variable information provided by the environment. In this way genes are depicted as the main causal factor of human development, letting aside the multicausality of illness, that can better be viewed from the concept of Probabilistic Determination. Ingold's thesis of self-assembly, which proposes that from the first moment of gestation, neurology and anatomy are the results of mutual modeling of biology, psychology and culture, opens the possibility to figure genes as a previous instance in the human development, but not its Sufficient Cause. As this theory is scientifically plausible opens the possibility to remove scientific basis to racist ideologies.

Dawidowski, Adriana Ruth. Deconstructing The Notion Of Human Genetic Causation: a Reflection Necessary To Face The Eugenic Threats That Emerge From The Rise Of Genetic Technologies. In: Anais do Congresso Internacional de Humanidades \& Humanização em Saúde [= Blucher Medical Proceedings, num.2, vol.1]. São Paulo: Editora Blucher, 2014. ISSN 2357-7282

DOI 10.5151/medpro-cihhs-10564 